\title{
The Impact of the Use of STEM Education Approach on the Blended Learning to Improve Student's Critical Thinking Skills
}

\author{
Suji Ardianti*, Dwi Sulisworo, Yudhiakto Pramudya, Widodo Raharjo \\ Ahmad Dahlan University, Indonesia
}

Received August 7, 2019; Revised September 27, 2019; Accepted February 20, 2020

Copyright $\odot 2020$ by authors, all rights reserved. Authors agree that this article remains permanently open access under the terms of the Creative Commons Attribution License 4.0 International License

\begin{abstract}
Educators believe that learning to utilize technology has opportunities to promote improvement in student learning performance. This optimism is undoubtedly expected to be implemented by students not only in cities but also in rural areas. The setting of this research was at the school in a rural area in Bima, Indonesia. This study explored the impact of blended learning by using the STEM education approach on improving students' critical thinking for physics subject in secondary schools. This research was quantitative research with pretest-posttest control group design. The experimental group was taught with blended learning that used the STEM education approach. The control group was prepared with conventional activities. Covariate in this study was prior knowledge. The dependent variable was critical thinking skills measured using an essay test. The statistical analysis used was ANCOVA which the error margin was 0.05 . The research found that blended learning with STEM education approach improved better critical thinking of students than conventional learning. The limitation of this study is that during online learning, students with less digital literacy still need assistance from teachers at the beginning of learning. The contribution in this study lies in a unique framework that is in the process of delivering knowledge using blended learning embedded the STEM education approach for high school physics lessons in the rural area.
\end{abstract}

Keywords Blended Learning, Critical Thinking Skills, Digital Literacy, Learning Innovation, Learning Performance, STEM Education

\section{Introduction}

Education in the 21st century requires skills in Sciences,
Technology, Engineering, and Mathematics (STEM) to face complex and challenging situations [1]. Also, STEM education helps students in developing skills of the 21st century that have capacities for innovation and allows students in problem-solving and quantitative reasoning [2]. STEM education approach is teaching and learning content, also the practice of interdisciplinary knowledge including sciences and math through engineering and design practice integration by using relevant technology engineering $[3,4]$. There are generally three forms of STEM integration at classroom: integrated content, integrated supporting content or integrated context $[1,5]$.

National Science Foundation (NSF) estimated that almost $20 \%$ of all jobs in the United States of America need knowledge and skills of STEM [6]. Skills related to STEM are: math, science, critical thinking, active learning, complex problem solving, and technology design [7]. Referring to the Programme for International Student Assessment (PISA) data in 2015, students expect to have a career related to sciences. Meanwhile, from interest aspect of male and female students on having a career related to science fields, almost all female students of Indonesia (92\%) expect jobs related to sciences and expect to have a career in the health field [8].

STEM approach gives positive impacts in the scientific process, investigation skills, and creative thinking of students. Also, it also develops student's reasoning skills, critical thinking skills, creativity, innovation, scientific literacy effects to students, and problem-solving skills [9-11]. Educators realize that critical thinking skills are essential in education today, mainly to deal with problems in an increasingly complex real life. This awareness encourages various studies related to these skills [12-14]. However, the reality is that level of critical thinking skill at one of the schools in Indonesia that become sample showed less than $10 \%$ subjects [15]. There were several aspects found, for example, students still found it difficult to 
understand the concept of dynamic fluid particularly the concept of continuity and Bernoulli equation with the application. The other one was that students paid less attention to the teacher during the teaching-learning process. Also, physics learning only presented formulations without knowing its objectives and many students were less self-confident. The effect was they usually gave the same answers with their classmates [16].

Referring to the teaching and learning process at the classroom, sometimes materials could not be optimally received by students because of the limited time of the face-to-face meeting. According to Government Regulation Number 19 the year 2017, the teacher is only obliged to have meeting a minimum of 24 hours per week [17]. For anticipating the lack, one of the alternatives is by using blended learning. Using blended learning could develop a student's skills and knowledge, and could be an opportunity to integrate innovative development and technology through online education [18, 19]. Also, learning situation applied in Indonesia experiences shifting of learning environment because of mobile learning technology [20].

In one side, there are several essential aspects in using blended learning such as providing students with adequate internet facilities, and students seem to depend on each other to upload assignments, which suggested to first introduce online learning implemented, and increasing student's motivation and responsibility in the learning process [21]. However, learning by using blended learning can develop students' critical thinking skills compared to the conventional one [22]. By observing the result of the existing researches, it seems that blended learning has not immensely been implemented in Indonesia. Therefore, this research would reveal the impacts of the implementation of the STEM education approach on blended learning.

\section{Method}

\subsection{Research Design}

This research was quantitative research with pretest-posttest control group design.

\subsection{Population}

The population used was a senior high school in West Nusa Tenggara, Indonesia, in the academic year of 2018/2019 that consisted of five classes with the number of students of 27 each. Samples were taken randomly to determine the experimental group and the control group from the courses of the research population.

The dependent variable in this research was the STEM education approach on blended learning by using Schoology on the experimental group and the conventional method of the control group. Independent variable focuses on critical thinking skills and used prior knowledge as the covariate.

\subsection{Instrument}

This research observed the improvement of student's cognitive viewed from the increase of critical thinking skills. Tools for observation are by using essay questions adopted from Ennis [23]. The level of Bloom's Taxonomy of issues is related to critical thinking indicators. The technique of data analysis used ANCOVA using SPSS 21.0. Here are test instruments of essential skills of thinking as shown in Table 1.

Table 1. The Rubric of Critical Thinking Skill Test Instrument

\begin{tabular}{|l|l|}
\hline $\begin{array}{l}\text { Critical Thinking } \\
\text { Indicator }\end{array}$ & $\begin{array}{l}\text { Critical Thinking } \\
\text { sub-Indicator }\end{array}$ \\
\hline Elementary clarification & $\begin{array}{l}\text { Answering questions "why" and } \\
\text { "how." }\end{array}$ \\
\hline Basic support & $\begin{array}{l}\text { Considering the use of the right } \\
\text { procedure in a question. }\end{array}$ \\
\hline Inference & Making inference based on facts. \\
\hline Advance clarification & Identifying arguments \\
\hline Strategy and tactics & Using logic strategies \\
\hline
\end{tabular}

The criteria of critical thinking skill scoring [24] are shown in Table 2.

\subsection{Learning Activities}

The topic is dynamic fluid. The dynamic fluid concept consists of the ideal fluid concept, continuity equation, Bernoulli's Law, and the application of Bernoulli's Law through Terrocelli, venturimeter, pitot pipe, and lift force on an aircraft [25].

Blended learning is a combination of online and face-to-face activities to optimize learning. The application used for online activities was one of the learning management systems called Schoology. Schoology application was available by clicking https://www.schoology.com/ or by downloading on Play Store using the smartphone. Before using Schoology application, the teachers and students should register for an account firstly during the learning process. Figure 1 shows the design of blended learning process.

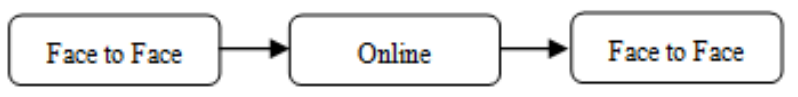

Figure 1. Design of Blended learning 
Table 2. Scoring Rubric of critical thinking skill

\begin{tabular}{|c|c|}
\hline Criteria of Problem's Answer & Score \\
\hline 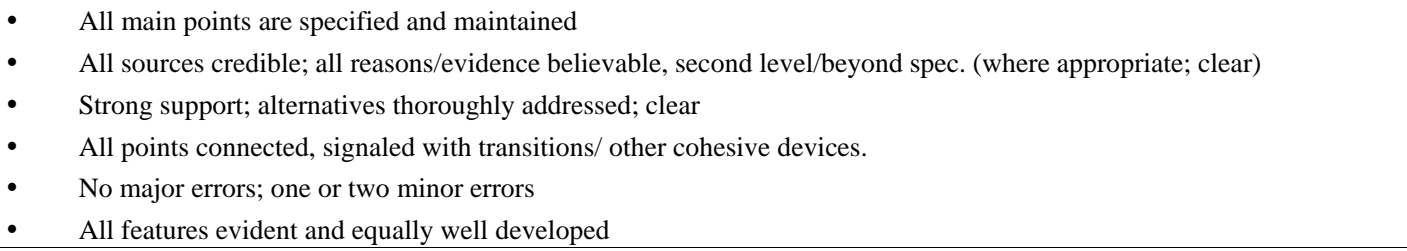 & 5 \\
\hline 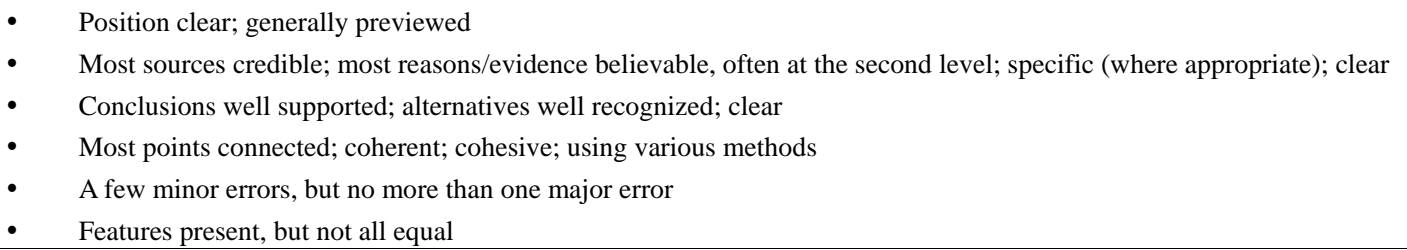 & 4 \\
\hline $\begin{array}{ll}\text { - } & \text { Bare bones; position clear; main point previewed } \\
\text { - } & \text { Some sources credible; reasons/evidence generally believable, sometimes second level; specific (where appropriate); } \\
\text { - } & \text { clear. } \\
\text { - } & \text { Moderate support; alternatives mentioned reasonably; some vagueness. } \\
\text { - } & \text { Some cohesion and coherence from relating to topic; plan is clear } \\
\text { - } & \text { Eseveloped; few major errors, some minor, meaning unimpaired; mastery of sentence construction } \\
\end{array}$ & 3 \\
\hline 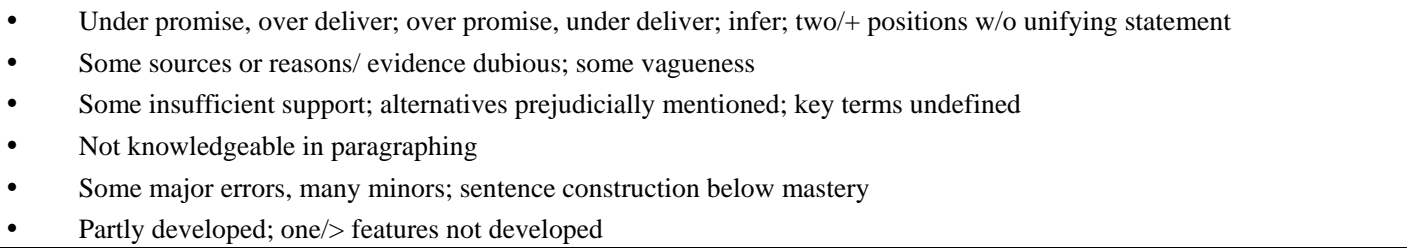 & 2 \\
\hline $\begin{array}{ll}\text { - } & \text { Confusing; attempted; main point unclear or shifts } \\
\text { - } & \text { Attempted; dubious sources; inaccurate; vague } \\
\text { - } & \text { Conclusions minimally supported; alternatives unmentioned; muddled; confused } \\
\text { - } & \text { Attempted; the plan is noticeable } \\
\text { - } & \text { Many major errors; confusion } \\
\end{array}$ & 1 \\
\hline 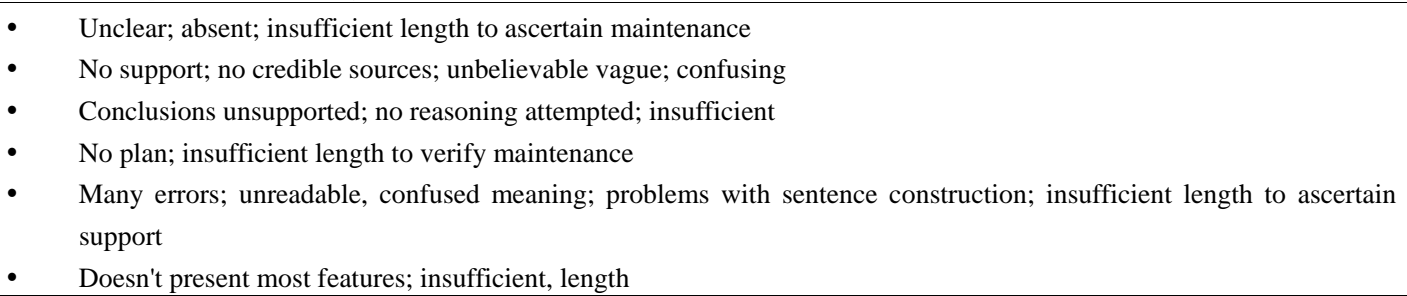 & 0 \\
\hline
\end{tabular}

In carrying learning out, the teacher prepared validated lesson plan, so it meets the learning objectives. Each step of activities as shown in Figure 2 used project-based learning. This strategy is suitable for STEM education approach; because the complexity of STEM education approach particularly requires to do the project and produce products that could be adjusted through project-based learning strategy. The implementation process of blended learning indeed contains learning with STEM education approach. STEM education approach refers to teaching and learning content and interdisciplinary practices covering sciences and math through engineering and design functional integration by using relevant technology engineering. 


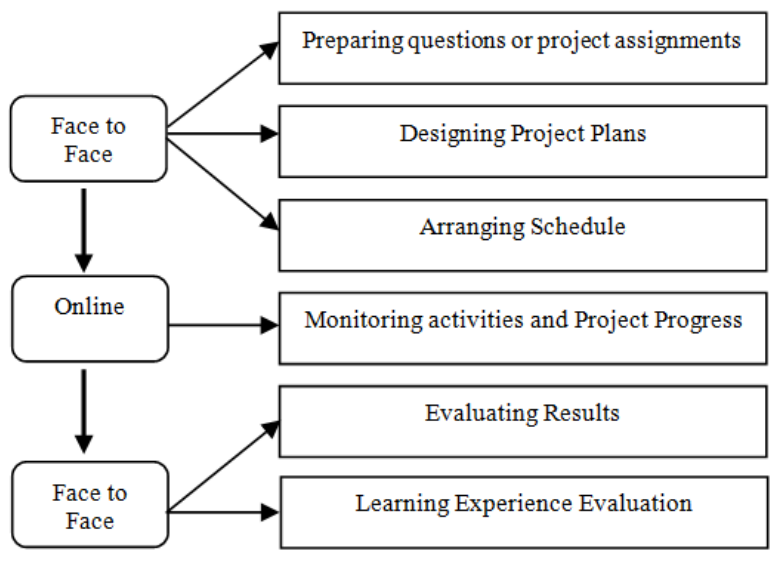

Figure 2. Learning activity

The phases of blended learning implementation with STEM education approach are:

- On the first meeting, the teacher explained the learning objectives and learning process.

- Next, the teacher divided students to five groups. Each group consisted of 5-6 students who are heterogeneous in sex and have previous learning achievement.

- $\quad$ On face-to-face learning, the teacher would ask the students to prepare questions and project assignment, design project plans, and arrange their schedule.
- On online learning, the teacher utilized Schoology to monitor student's activities and the project progress. If students wanted to ask something, they could interact with each other via Schoology. Also, the teacher also prepared materials to complete materials that might be lack of a face-to-face meeting.

- $\quad$ On face-to-face meeting, the teacher and students would evaluate their results or products. Also, the teacher would give opportunities to present the conclusions made by students and assess learning experience during the process of learning activities. The score would influence each student's group score.

Online learning activities referred to the use of Schoology outside of school learning hours. Teacher and students used Schoology as a forum for discussions related to projects agreed upon during school hours. The following is a screenshot of one of the student and teacher activities in Figure 3, Figure 4, and Figure 5.

The figures show various online learning activities. Those figures show that the interaction carried out tends to the problems faced by students to do their project tasks. The positive side is the existence of repeated posts from students to teachers and vice versa to obtain clarity of activity. The teacher's ability to manage interactions that flow with students influences the level of willingness of students to communicate further.

Agus A.

ada buk, kelompok kami mau buat venturimeter bu

$5: 35 \mathrm{am} \cdot$ Like

Agus A.

sudah dirancang sesuai prosedur, tapi bingung cara paham sama konsep fisikanya'

$5: 36 \mathrm{am} \cdot$ Like

Suji Ardianti

konsep kerjanya sederhana dek, ntar masukin air dalam pipanya. setelah itu lihat minyak yang ada pada selang. tekanan air mempengaruhi minyak dalam selang.

$$
5: 39 \mathrm{am} \cdot \text { Like }
$$

Figure 3. Teacher and student discussed on the project of simple venturimeter. Agus A. (student) had designed the venturimeter as the procedure but it did not work. Suji Artdianti (teacher) explained the system mechanism

Amalia I

begini bu, masi bingung airnya sedikit keluar. pas semprotannya di pompa. kenapa ya bu

$$
\text { 5:51 am · Like }
$$

Suji Ardianti

pasti masih ada rongga udara yg masuk dek. coba diperhatikan lagi ya.

$$
\text { 5:52 am · Like }
$$

Figure 4. Teacher and student discussed on the project of simple spray. Amalia I (student) asked the solution for the less water from the nozzle of the simple spray. Suji Ardianti (teacher) explained the root problem 
M Iqbal T.

assalamualaikum ibu, mau tanya. untuk nampan yang disuru bawa buat

praktikum kayak gimana bu

$5: 54 \mathrm{am} \cdot$ Like

M Iqbal T.

terus botolnya sebesar apa

5:54 am · Like

Suji Ardianti

wa'alaykum salam. ok saya jelaskan lagi. nampan itu untuk nampung air ya. kalo botol yg ukuran $600 \mathrm{ml}$ lah

$5: 55 \mathrm{am} \cdot$ Like

Figure 5. Teacher and student discussed on the next project activities. M Iqbal (student) made the confirmation on the next assignment. Suji Ardianti (teacher) described it

\section{Result}

\subsection{Validity and Reliability}

The critical thinking skills' tests consist of ten essay questions. The number of participants was 27 students. From the calculation of item validity aspect (alpha 0.05), the result showed that number of valid questions was five items. The reliability score was 0.419 .

\subsection{Normality and Homogeneity Test}

Normality test was carried out by using the one-sample Kolmogorov-Smirnov test for pretest and posttest data of experimental and control groups. By using SPSS 21.0, the result is the data group gives significant score online Asymp. Sig. (2-tailed) For experimental group it shows 0.563 and 0.198 each, while for control group it shows 0.100 and 0.175 . Based on the Sig score, all data results in Sig score that is higher than 0.05. Therefore, there were eight data groups in this research come from a normally distributed population. It means that one of the preconditions of F-test has been fulfilled.

Homogeneity test used homogeneity criteria of data variant comparing significance score and alpha $(\alpha)$. The guideline for decision making on homogeneity is stated homogenous if the error probability is less than 0.05; then data variant is homogenous, vice versa. By using SPSS 21.0, the result is the data group gives a significant score for critical thinking skill. Significance level based on mean is 0.670 . Thus, the group variant of posttest of experimental and control groups is similar to homogenous. Therefore, the samples from the population were homogenous.

\subsection{Validation Result of Essay Questions}

Essay questions used in this research adopted indicators explained by [23]. Before using, they first passed the validation phase carried out by some experts. There are several components observed in the question content, such as material, construction, and language aspects. The description of validation result data by experts is on following Table 3 .

Table 3. The Result of Expert Validation for Critical Thinking Skil Essay Questions

\begin{tabular}{|c|c|c|c|}
\hline \multirow{2}{*}{ Expert } & \multicolumn{3}{|c|}{ Components } \\
\cline { 2 - 4 } & Material & Construction & Language \\
\hline Physics Subject Expert 1 & 23 & 20 & 18 \\
\hline Physics Subject Expert 2 & 23 & 21 & 18 \\
\hline Physics Subject Expert 3 & 24 & 24 & 20 \\
\hline
\end{tabular}

Based on Table 3, the validity score of each component is nearly perfect towards questions used. Meanwhile, viewed from the content validity coefficient from the three validators, the score of average content validity coefficient is 1 . If it is more than 0.8 so content validity coefficient is stated high. Figure 6 shows the flowchart of data of physics expert question validity.

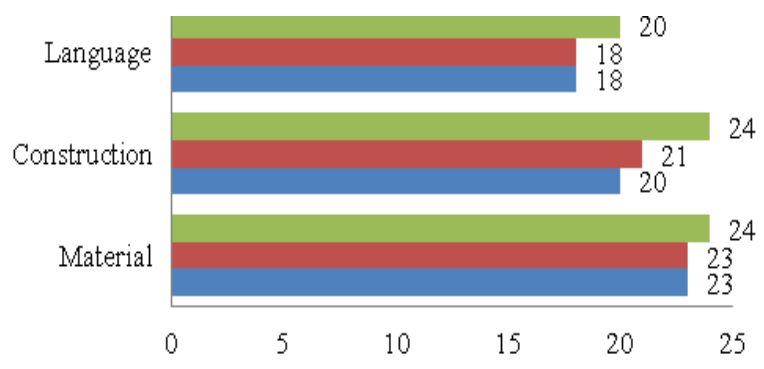

Physics Subject Expert 3 Physics Subject Expert 2

-Physics Subject Expert 1

Figure 6. Flowchart of data of physics expert question validity

\subsection{The Score of Prior Knowledge}

Based on data of pretest score of experimental and control groups, mean, media, modus, minimum and maximum scores were calculated. Table 4 describes data of 
prior capability of experimental and control groups.

Table 4. Data of Prior Knowledge Score

\begin{tabular}{|c|c|c|c|c|c|c|}
\hline Group & N & Mean & Median & Modus & Min. & Max. \\
\hline Experiment & 27 & 48,4 & 48 & 44 & 32 & 56 \\
\hline Control & 27 & 46,7 & 48 & 48 & 36 & 56 \\
\hline
\end{tabular}

On Table 4, the mean of the experimental group is 48.8 and median is 48 . Meanwhile, the average of the control group is 46.7 , and the average is 48 .

\subsection{The Score of Student's Critical Thinking Skill}

Data of student's critical thinking skill of experimental and control groups can be observed on the attachment. Based on the data, we can calculate the mean, the median, the modus, the minimum, and the maximum score. Table 5 shows the description of post-test data of experimental group and control group.

Table 5. Data for Critical Thinking Skill Score

\begin{tabular}{|c|c|c|c|c|c|c|}
\hline Group & $\mathbf{N}$ & Mean & Median & Modus & Min & Max \\
\hline Experiment & 27 & 81,5 & 80 & 80 & 72 & 92 \\
\hline Control & 27 & 60,6 & 60 & 60 & 52 & 72 \\
\hline
\end{tabular}

On Table 5, the mean of the experimental group is 81.5 , and the median is 80 . Meanwhile, the mean of the control group is 60.6, and the average is 60 . The score of each indicator of critical thinking skill explained by Ennis (2011) has been developed for experimental and control groups as in Table 6.

Table 6. Data for each indicator of critical thinking skill

\begin{tabular}{|c|c|c|c|}
\hline No & $\begin{array}{c}\text { The indicator of critical } \\
\text { thinking skill }\end{array}$ & $\begin{array}{c}\text { Experimenta } \\
\text { I Group }\end{array}$ & $\begin{array}{c}\text { Control } \\
\text { Group }\end{array}$ \\
\hline 1 & Elementary clarification & 117 & 102 \\
\hline 2 & Basic support & 109 & 81 \\
\hline 3 & Inferences & 99 & 72 \\
\hline 4 & Advances clarification & 95 & 72 \\
\hline 5 & Strategy and tactics & 110 & 67 \\
\hline \multicolumn{2}{|c|}{ Average } & 106 & 78.8 \\
\hline
\end{tabular}

Based on the data result of critical thinking skill indicators, the indicator that got the highest score of each group is elementary clarification, while the lowest occurs on control group which is strategy and tactics. Figure 7 shows the flowchart of the critical thinking skill score.

In Figure 7, it shows that in the experimental class and the control class the highest acquisition score occurs on elementary clarification indicators. While for the experimental group, the lowest score happened on clarification advances indicators, and the control class on the strategy and tactics indicator. The average score obtained when viewed from both groups, and it turns out that the experimental group is higher than the control group.

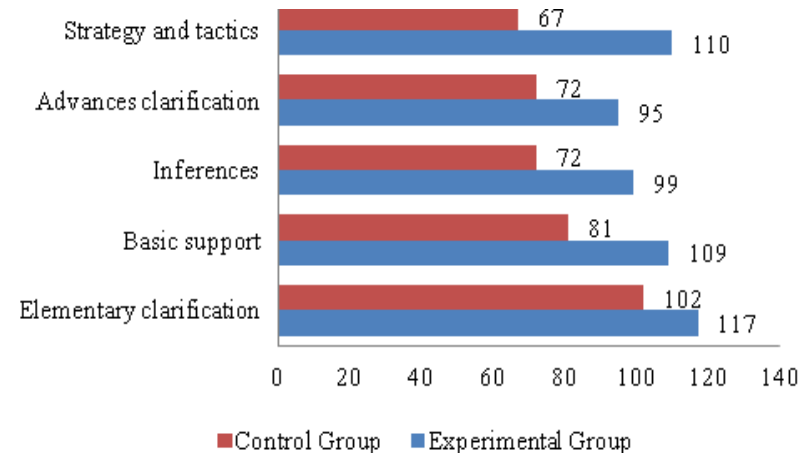

Figure 7. Flowchart of critical thinking skill per indicator

\subsection{ANCOVA Test}

Using one covariant variable analysis technique, by controlling prior knowledge towards the linear relationship between previous capability and student's critical thinking skill, it shows significance score which is less than 0.05 . Data obtained is 0.036 . If viewed the influence of the difference of STEM education approach on blended learning towards student's critical thinking skill, it seems that significance score (group division) for STEM education approach on blended learning is 0.000 . Since the score is less than 0.05 , so it can be concluded that without the influence of prior knowledge, on the credibility level of $95 \%$, there is an influence of difference of STEM education approach on blended learning towards critical thinking skill.

The influence of student's prior knowledge and STEM education approach on blended learning towards student's critical thinking skill simultaneously can be viewed from significance number on Corrected Model. It can be seen that a significant amount is 0.000 . Since the significant number is less than 0.05 , so it implies that simultaneously student's prior knowledge and learning used influence critical thinking skill. Table 7 and Table 8 respectively describe the analysis of both the control and the experimental groups.

Table 7. Descriptive Statistics of Student's Critical Thinking

\begin{tabular}{|c|c|c|c|}
\hline Group & Mean & Std. Deviation & N \\
\hline Experiment & 81.4815 & 5.10181 & 27 \\
\hline Control & 60.5926 & 5.16839 & 27 \\
\hline Total & 71.0370 & 11.70545 & 54 \\
\hline
\end{tabular}

Based on Table 7, the experiment group has higher mean of critical thinking score (81.48) than the control group (60.59). The standard deviations are almost the same for both groups (about 5.1).

Table 8 implies that the prior knowledge has the significant effect on the critical thinking skill. This covariate should be considered to find the clear effect of the learning strategy to the critical thinking skills. 
Table 8. ANCOVA result

\begin{tabular}{|c|c|c|c|c|c|}
\hline Source & $\begin{array}{c}\text { Type III Sum } \\
\text { of Squares }\end{array}$ & DF & $\begin{array}{c}\text { Mean } \\
\text { Square }\end{array}$ & F & Sig. \\
\hline $\begin{array}{c}\text { Corrected } \\
\text { Model }\end{array}$ & $6004.477 \mathrm{a}$ & 2 & 3002.239 & 121.766 & .000 \\
\hline Intercept & 2282.613 & 1 & 2282.613 & 92.579 & .000 \\
\hline $\begin{array}{c}\text { Prior } \\
\text { knowledge }\end{array}$ & 113.810 & 1 & 113.810 & 4.616 & .036 \\
\hline Groups & 5470.897 & 1 & 5470.897 & 221.890 & .000 \\
\hline Error & 1257.449 & 51 & 24.656 & & \\
\hline Total & 279760.000 & 54 & & & \\
\hline $\begin{array}{c}\text { Corrected } \\
\text { Total }\end{array}$ & 7261.926 & 53 & & & \\
\hline
\end{tabular}

\section{Discussion}

Based on the results of the research that have been revealed and presented in the previous part, the beginning of the learning score of 5 item essay questions of critical thinking skill as prior knowledge of the experimental and control groups was categorized fair and not significant. T-test towards student's prior knowledge and learning interest shows that by using a significant level of $5 \%$ or 0.05 , there is no significant difference in prior knowledge between two dependent variables. From output data result on Independent Sample t-test which is a score of 2-tailed error level that is 0.236 (higher than .05) on critical thinking. Therefore, $\mathrm{H}_{0}$ is accepted. It means "there is no difference in critical thinking skill level between two groups."

Next, after the implementation of STEM education approach on blended learning, posttest score of student's critical thinking skill is categorized fair, so STEM education approach on blended learning gives a positive influence towards the increase of student's critical thinking skill and learning interest. The rise of student's critical thinking skill can be identified from each indicator given when pretest and posttest generally increase in the two groups, even though there is a significant difference between the two groups.

The highest increase occurs in the group using the STEM education approach on blended learning on the indicator of "Elementary clarification" (Table 4). The increase in this aspect occurs because students had opportunities to actively participate in learning by giving clarification related to presented questions. The lowest increase occurs on "Advance clarification."

After the implementation of STEM education approach on blended learning on experimental group, it seems that the average increase of student's critical thinking skill achievement is good increment compared to the conventional learning activity. The difference in the rise of student's critical thinking skill of each group can be explained from the approach and learning process on each group during learning. On the group using STEM education approach on blended learning, the learning process is more effective and active in developing student's critical thinking skill. In another side, on the implementation of STEM education approach, students are guided to find the answer of materials taught independently, so the learning process is more active and student-centered, or students play the role as the center of learning activities [26][27]. Table 9 shows the finding on the summary of $\mathrm{N}$-gain score (the number of the increment to the prior score).

Table 9. N-gain of the critical thinking skills

\begin{tabular}{|c|c|c|}
\hline Group & N-gain & Criteria \\
\hline Experiment & 0.60 & Fair \\
\hline Control & 0.26 & Low \\
\hline
\end{tabular}

Table 9 shows that by using blended learning with STEM education approach student's critical thinking skills increase 0.60 with fair criteria. From the data in Table 9, the blended learning with STEM education approach is better in improving essential thinking skill and learning interest compared to the conventional one. The statement is also supported by the result of t-test on student's critical thinking skill and learning interest by using SPSS 21.0 by concluding that $\mathrm{H}_{0}$ is rejected. It means "there is a significant increase of student's critical thinking skill and learning interest by using blended learning with STEM education approach compared to the conventional one" on the significance level of $5 \%$ or 0.05 .

As the additional information, based on the result of the student understanding of the concepts, the majority of students who taught using blended learning with STEM education approach have understood the dynamic fluid subject. The percentage of the student who passed the minimum completeness criteria was $81.5 \%$. It is higher than the other group that was $60.6 \%$. From this analysis, it means that blended learning with STEM education approach is better than conventional learning. It is because learning activities that are more actively involve students and the teacher only plays a role as a facilitator or is student-centered.

The result of this research shows that using blended learning with STEM education approach gives better influence to improve student's critical thinking skill and learning interest than conventional learning. It is proven by analysis by using ANCOVA test. The results showed that there was a difference of influence that is convincing between prior knowledge and the student's critical thinking skill.

With the result as previously explained, it seems that student's prior knowledge has a contribution towards the level of student's critical thinking skill of senior high school in Nusa Tenggara Barat, Indonesia. Based on the result description as previously explained, it seems that student's prior knowledge contributes towards the level of critical thinking skill, so it strengthens internal validity 
revealed.

In this study, the applied learning strategies influence increasing critical thinking skills. This finding supports other similar research findings. Several factors need to be considered in more detail. In this study, several aspects can be examined as separate variables, namely: the learning management system used, teacher and student interactions during blended learning, mater teaching characteristics, and student characteristics. The impact seen is still in the outcome, namely critical thinking skills. But the effect on output such as the level of interaction related to teacher presence, social presence and academic presence has not been studied. While many researchers still see many opportunities that can be done to make online learning run optimally.

\section{Conclusions}

The strategy of learning blended learning based on the STEM education approach carried out using the learning management system has the potential to increase the critical thinking skills of middle school students. In this study, prior knowledge is a variable that can be used as a predictor for enhancing critical thinking skills.

\section{Acknowledgements}

This research is funded by the Ministry of Research, Technology and Higher Education of the Republic of Indonesia under Post-graduate Research Grant Scheme, the Year 2019.

\section{REFERENCES}

[1] Premnadh M. Kurup, Xia Li, G. Powel, M. Brown. Building future primary teachers' capacity in stem: based on platform of beliefs, understandings, and intentions, International Journal of STEM Education, (Online), DOIhttp://doi.org/1 0.1186/s40594-019-0164-5. Vol.6, No.10, 2019.

[2] M. S. Corlu, R. M. Capraro, M. M. Capraro. Introducing STEM Education: Implications for Education Our Teachers for the Age of Innovation. Egitim ve Bilim. Journal of Education and Science, Vol. 39, No.171, 74-85, 2014.

[3] S. I. Van Aalderen-Smeets, J. H. Walman van der Molen, I. Xenidou-Dervou. Implicit STEM ability beliefs predict secondary school students' STEM self-efficacy beliefs and their intention to opt for a STEM field career. Journal of Research in Science Teaching, Vol. 56, No. 4, 465-485, 2019.

[4] P. Davidson, S. Roslan, Z. Omar, M. Abdullah Chong, S. Y. Looi, T. T. X. Neik, B. Young. Validation of competing structural models of inter-relationships in the teaching-learning ecosystem for two Malaysian STEM courses. Asia Pasific Education Review, Vol. 20, No.1, 15-36, 2019.

[5] C. C. Johnson, E. E. Peters-Burton, T. J. Moore. STEM road map: A framework for integrated STEM education, Routledge, 2015.

[6] NSF. The STEM workforce: not one, but many from National Science Foundation: STEM Workforce, 2016, Retrieved March 19, 2019, Report: http://nsf.gov/nsb/publi cations/2015/nsb201510.pdf.

[7] A. P. Carneyale, H. Smith, M. Melton. STEM, Washington DC, Georgetown University Center on Education and the Workforce, 2014.

[8] OECD. Programme for International Student Assessment (PISA) Result From PISA 2015, Indonesia, OECD Publishing, 2016.

[9] R. Mohamad Sattar, Z. Norsalehan, H. Lilia, Abd Rauf, Rose Amnah. Impact of Integrated STEM Smart Communities Program on Students Scientific Creativity, Journal of Engineering Science and Technology, Vol. 11, 80-89, 2018.

[10] K. M. Meyrick. How STEM Education Improves Student Learning. Meridian: A K-12 School Computer Technologies Journal. Vol. 14, No.1, 1-6, 2011.

[11] L. Yuliati, A. A. Hapsari, F. Nurhidayah, L. Halim. Building Scientific Literacy and Physics Problem Solving Skills trought Inquiry-Based Learning for STEM Education, In Journal of Physics: Conference Series, Vol. 1108, No.1, [012026], 2018.

[12] K. Roohr, M. Oliver-Aguilar, G. Ling, S. Rikoon. A multi-level modeling approach to investigating students' critical thinking at higher education institutions, Assessment and Evaluation in Higher Education, Vol. 44, No.6, 946-960, 2019.

[13] Z. H. Wan, M. H. M. Cheng. Classrom learning environment, critical thinking and achievement in an interdisciplinary subject: A study of Hong Kong secondary school graduates, Educational Studies, Vol. 45, No. 3, 285-304, 2019.

[14] H. E. Mohottala. Improving critical skills using wikis and CGPS in a physics classroom, Physics Teacher, Vol.54, No.7, 427-430, 2016.

[15] Q. Amalia, Y. Hartono, I. Indaryani. Students' critical thinking skills in modeling based learning, The 3rd Sriwijaya University Learning and Education International Conference, IOP Conf. Series Journal of Physics, Vol. 11, No. 66, 1-6, 2019.

[16] P. L. Y. Kristian, C. Cari, W. Sunarno. The analysis of the mathematics concept comprehension of senior high school student on dynamic fluid material, International Conference on Science Education (ICoSEd), IOP Conference Series: Journal of Physics, Vol. 10, No. 06, 1-5, 2018.

[17] Kemendikbud. Tentang Hari Sekolah, Direktorat Jendral Pendidikan Dasar dan Menengah Umum, Jakarta, 2017.

[18] J. Jani, R. Muszali, S. Nathan, M. S. Abdullah. Blended Learning Approach Using Frog VLE Platform Towards Students' Achievent in Teaching Games for Understanding, Journal of Fundamental and Applied Science, Vol. 10, No. 5S, 1130-1141, 2018. 
32 The Impact of the Use of STEM Education Approach on the Blended Learning to Improve Student's Critical Thinking Skills

[19] K. Thorne. Blended Learning: How to Integrated Online and Traditional Learning, Library of Congress Cataloging-in-Publication Data, The United States of America, 2003.

[20] D. Sulisworo, M. Toifur. The role of mobile learning on the learning environment shifting at high school in Indonesia, International Journal Mobile Learning and Organisation, Vol. 10, No. 3, 157-170, 2016.

[21] P. Purnawarman, Susilawati, W. Sundayana. The Use of Edmodo In Teaching Writing In A Blended Learning Setting, Indonesian Journal of Applied Linguistics, Vol. 5, No. 2, 242-252, 2016.

[22] Ö. Korkmaz, U. Karakuṣ. The Impact of Blended Learning Model on Student Attitudes Towards Geography Course and Their Critical Thinking Dispositions and Levels, The Turkish Online Journal of Educational Technology, Vol. 8, No. 4, 51-63, 2009.

[23] R. H. Ennis. The Nature of Critical Thinking: An Outline of Critical Thinking Depositions and Abilities, University of Illinois, 2011.

[24] M. Frinken, R. H. Ennis. Illinois Critical Thinking Essay Test, Illinois Critical Thinking Project Department of Educational Policy Studies University of Illinois, (Online), (https://www.criticalthinkingnet/llCTEssayTestFinken-Enn is12-1993LowR.pdf)1993.

[25] D. K. Randall. Physics for Scientists and Engineers: A Strategic Approach with Modern Physics, 4th edition, Pearson Education, United States of America, 2017.

[26] S. J. Lou, R. C. Shih, C. R. Diez, K. H. Tseng. The Impact of Problem Based Learning Strategies on STEM Knowledge Integration and Attitude, an Exploratory Study Among Female Taiwanese Senior High School Students, International Journal of Technology and Design Education, Springer,(Online),(https://www.springerprofessional.de/en/ the-impact-of-problem-based-learningstrategies-on-stem-k nowledg/5490704), accessed on 13 February 2019, pp. 195-215, 2011.

[27] N. Khoiriyah, Abdurrahman, I. Wahyudi. Implementasi Pendekatan Pembelajaran STEM untuk Meningkatkan Kemampuan Berpikir Kritis Siswa SMA pada materi Gelombang Bunyi, Jurnal Riset Kependidikan dan Pendidikan Fisika, Vol. 5, No. 2, 53-62, 2018. 